\title{
PENGEMBANGAN MODUL PEMBELAJARAN IPA BERBASIS INKUIRI TERBIMBING UNTUK MENINGKATKAN KETERAMPILAN PROSES DASAR SAINS PESERTA DIDIK KELAS IV MI/SD
}

\author{
Erma Yulita \\ STAI AuliaurrasyidinTembilahan Riau \\ erma.yulita1989@gmail.com
}

Naskah diterima : 12 September 2018, direvisi : 20 September 2018, disetujui : 15 Oktober 2018

\begin{abstract}
Abstrak
Penelitian ini bertujuan untuk mengembangkan modul pembelajaran IPA berbasis inkuiri terbimbing yang valid untuk meningkatkan keterampilan proses dasar sains peserta didik kelas IV MI/SD. Penelitian dan pengembangan ini menggunakan model Borg and Gall. Instrumen penilaian berupa lembar angket, lembar observasi dan butir soal. Adapun hasil perhitungan validasi modul pembelajaran IPA berbasis inkuiri terbimbing berdasarkan penilaian ahli materi sangat baik (SB) dengan skor 132 dan tingkat persentase keidealan 90,20\%. Penilain ahli media sangat baik (SB) dengan skor 107 dan tingkat persentase ideal 93,71\%. Penilaian ahli bahasa sangat baik (SB) dengan skor 21 dan tingkat persentase 82,5\%. Penilaian ahli pembelajaran IPA dan inkuiri terbimbing sangat baik (SB) dengan skor 69 dan tingkat persentase keidealan $84,07 \%$. Sedangkan respon siswa terhadap produk yang dikembangkan sangat baik (SB) dengan persentase keidealan sebesar 94,21\%. Sedangkan validasi keterampilan proses dasar sains ditentukan berdasarkan hasil ujipaired sample t-test, dengan hasil perhitungan $t_{\text {hitung }} 3,065$ dan $t_{\text {tabel }} 2$ 2,064, karena $t_{\text {hitung }}>t_{\text {tabel, }}$ maka diketahui bahwa terjadi peningkatan keterampilan proses dasar sains yang signifikan sesudah menggunakan modul pembelajaran IPA berbasis inkuiri terbimbing. Oleh karena itu, dapat ditarik kesimpulan bahwa modul pembelajaran IPA berbasis inkuiri terbimbing yang dikembangkan sudah layak dan dapat digunakan untuk meningkatkan keterampilan proses dasar sains siswa kelas IV SD/MI.
\end{abstract}

Kata kunci: Modul, Pembelajaran IPA, Inkuiri Terbimbing, Keterampilan Proses Dasar Sains.

Pengutipan: Erma Yulita. (2018). Pengembangan Modul Pembelajaran IPA Berbasis Inkuiri Terbimbing untuk. Meningkatkan Keterampilan Proses Dasar Sains Peserta Didik Kelas IV MI/SD. JMIE: Journal of Madrasah Ibtidaiyah Education, 2(2), 2018, 165-180. jmie.v2i2.70.

Permalink/DOI: http://dx.doi.org/ 10.32934/jmie.v2i2.70 


\section{PENDAHULUAN}

Pembelajaran IPA atau sains merupakan bagian dari kehidupan. Oleh karena itu, seiring perkembangan ilmu pengetahuan dan teknologi dalam sistem kehidupan, maka pelaksanaan pembelajaran IPA juga harus mengalami perkembangan. Sebagaimana yang dikatakan Chiappetta dalam Fatonah dan Prasetyo bahwa hakikat sains adalah a way of thinking (cara berpikir), a way of investigating (cara penyelidikan) and a body of knowledge (sekumpulan pengetahuan) (Siti Fatonah dan Zuhdan K. Prasetyo, 2014:6). Sejalan dengan pernyataan tersebut, maka konten Ilmu Pengetahuan Alam tidak hanya memuat sejumlah teori tetapi juga sejumlah kegiatan-kegiatan praktik dan penyelidikan yang menuntut peserta didik untuk aktif dan terampil menggunakan berbagai keterampilan dalam proses pembelajaran IPA. Keterampilan proses tersebut dalam pembelajaran IPA dikenal dengan keterampilan proses sains.Oleh karena itu, keterampilan proses menjadi hal wajib yang harus dilatih dan dikembangkan sejak dini melalui pembelajaran IPA.

Akan tetapi pada kenyataannya, merujuk pada beberapa hasil penelitian terdahulu dan sudah dipublikasikan diketahui bahwa keterampilan proses sains siswa masih rendah. Masih rendahnya keterampilan proses sains tersebut merujuk pada hasil penelitian Ai Hayati Rahayu dan Poppy Anggraeni diketahui bahwa keterampilan proses sains siswa Sekolah Dasar di Kabupaten Sumedang secara keseluruhan masih rendah dengan nilai rata-rata Keterampilan Proses Sains sebesar 9,8. Sedangkan peraspek keterampilan proses dasar sains siswa Sekolah Dasar di Kabupaten Sumedang juga masih rendah dengan persentase sebesar 49,7\%. (Ai Hayati Rahayu dan Poppy Anggraeni, 2017:32). Pernyataan tersebut dikuatkan berdasarkan hasil penelitian yang dilakukan Esti Yuli Widayanti diketahui bahwa Persentase tingkat penguasaan Keterampilan Proses Sains Dasar Kelas Atas siswa untuk semua keterampilan proses sains siswa hanya mencapai rata-rata 54,47\% dengan kategori penguasaan siswa mayoritas belum begitu tinggi/sedang. (Esti Yuli Widayanti, 2015:195)

Selain itu, penelitian dengan bidang kajian keterampilan proses sains yang dilakukan Juhji juga diketahui bahwa berdasarkan observasi di kelas VI B SD Islam AlIkhlas Cipete, terlihat aktivitas keterampilan proses sains siswa belum muncul. Hal ini dikarenakan beberapa faktor, seperti masih terbiasa dengan budaya lama yaitu proses pembelajaran berpusat pada guru, sehingga aktivitas keterampilan proses sains belum berkembang secara optimal. Selain itu, beberapa siswa masih belum melakukan pengamatan menggunakan panca indera yang sesuai, bertanya dalam menyusun hipotesis meskipun telah dijelaskan oleh guru pada pertemuan sebelumnya, belum aktif mengkomunikasikan hasil pembelajaran dan belum dapat menyusun kesimpulan 
pembelajaran sesuai hasil yang didapatkan. Berdasarkan hasil penelitian hanya ada satu keterampilan proses sains yang mencapai indikator keberhasilan $(>70 \%)$. Tiga keterampilan proses sains yakni mengamati, mengukur, dan melakukan pekerjaan sejak siklus 1 sudah mencapai lebih dari 70\%, sementara empat keterampilan proses sains lainnya yakni memprediksi, menginterpretasi data, mengkomunikasikan, dan menyimpulkan tidak mengalami peningkatan. (Juhji, 2016: 62 dan 68).

Berdasarkan hasil temuan penelitian tersebut, maka salah satu faktor yang mempengaruhi masih rendahnya keterampilan proses dasar sains siswa adalah pelaksanaan pembelajaran yang masih berpusat pada guru (teacher center). Oleh karena itu, pembelajaran IPA harus diarahkan pada pembelajaran yang berpusat pada siswa. Salah satunya dengan menerapkan inkuiri. Pembelajaran inkuiri adalah rangkaian kegiatan belajar yang melibatkan secara maksimal seluruh kemampuan siswa untuk mencari dan menyelidiki secara sistematis, logis, analitis, sehingga mereka dapat merumuskan sendiri penemuannya dengan penuh percaya diri (Trianto, 2009:166). Akan tetapi karena penelitian ini dilakukan ditingkat MI/SD, maka proses pelaksanaannya dilakukan di bawah bimbingan atau arahan guru, dalam konteks ini guru bukan mendominasi tetapi memancing atau memfasilitasi siswa untuk terlibat aktif dalam kegiatan pembelajaran. Pola inkuiri seperti ini lebih dikenal dengan inkuiri terbimbing. Inkuiri terbimbing adalah salah satu pendekatan dimana siswa memperoleh pedoman atau petunjuk sesuai dengan apa yang mereka butuhkan (Rizki Nurhidayah, 2015).

Akan tetapi penerapan inkuiri terbimbing dalam pembelajaran IPA masih sulit diimplemetasikan karena masih terbatasnya bahan ajar berbasis inkuiri terbimbing. Oleh karena itu, diperlukan bahan ajar yang sifatnya sesuai dengan karakteristik pembelajaran dan komprehensif dalam membahas satu pokok bahasan materi, salah satunya modul, karena modul merupakan bahan belajar yang disusun secara sistematis dengan bahasa yang mudah dipahami oleh siswa dan disesuaikan dengan tingkat pengetahuan dan usianya, agar mereka dapat belajar sendiri (mandiri) dengan bantuan atau bimbingan yang minimal dari guru (Andi Prastowo, 2014:209). Oleh karena itu, modul yang sifatnya dinamis dan mandiri tersebut, jika dikembangkan dan dikombinasikan dengan tahapan pembelajaran inkuiri terbimbing, maka dapat membantu siswa untuk terlibat aktif dalam mengembangkan kemampuan berpikir sebagai wujud pengembangan rasa ingin tahu (insight), melalui langkah-langkah inkuiri terbimbing, sehingga dapat meningkatkan keterampilan dasar siswa yang meliputi keterampilan observasi (pengamatan), communicating (mengkomunikasikan hasil pengamatan), classifying (mengklasifikasi), 
measuring (mengukur), inferring (membuat kesimpulan) dan predicting (memprediksi). (Conny Semiawan, 1990: 18)

Menanggapi hal tersebut, maka peneliti berminat mengembangkan bahan ajar dalam bentuk modul pembelajaran IPA yang dikembangkan dalam bentuk hard copy full colour dilengkapi dengan tahapan pembelajaran inkuiri terbimbing, gambar-gambar yang ditampilkan kontektual, penulisan dan tata bahasa disesuaikan dengan tingkat perkembangan siswa, kegiatan dalam modul terdiri dari kegiatan-kegiatan mari berpikir, mari membaca, mari cari tahu, mari diskusi, mari bersyukur, mari berkreasi, mari uji pemahaman. Kegiatan-kegiatan tersebut diarahkan agar siswa dapat mengembangkan keterampilan proses dasar dalam pembelajaran IPA yang disesuaikan dengan tuntutan kurikulum 2013. Oleh karena itu, penelitian ini memfokuskan pada "Pengembangan Modul Pembelajaran Ilmu Pengetahuan Alam Berbasis Inkuiri Terbimbing untuk Meningkatkan Keterampilan Proses Dasar Sains Siswa Kelas IV MI/SD”.

\section{Metode Penelitian}

\section{Jenis Penelitian}

Penelitian ini termasuk ke dalam rumpun penelitian dan pengembangan atau Research and Development (R\&D). Sebagaimana yang dikemukakan Borg and Gall dalam Arifin, "research and development is a powerful strategy for improving practice. It is a process used to develop and validate educational product."(Zainal Arifin,2011:12). Adapun prosedur yang digunakan dalam penelitian menggunakan prosedur pengembangan Borg and Gall dengan langkah-langkah atau prosedur pelaksanaan penelitian, (Sugiono, 2015:37) sebagai berikut:

Gambar 1: Prosedur R \& D Model Borg\& Gall

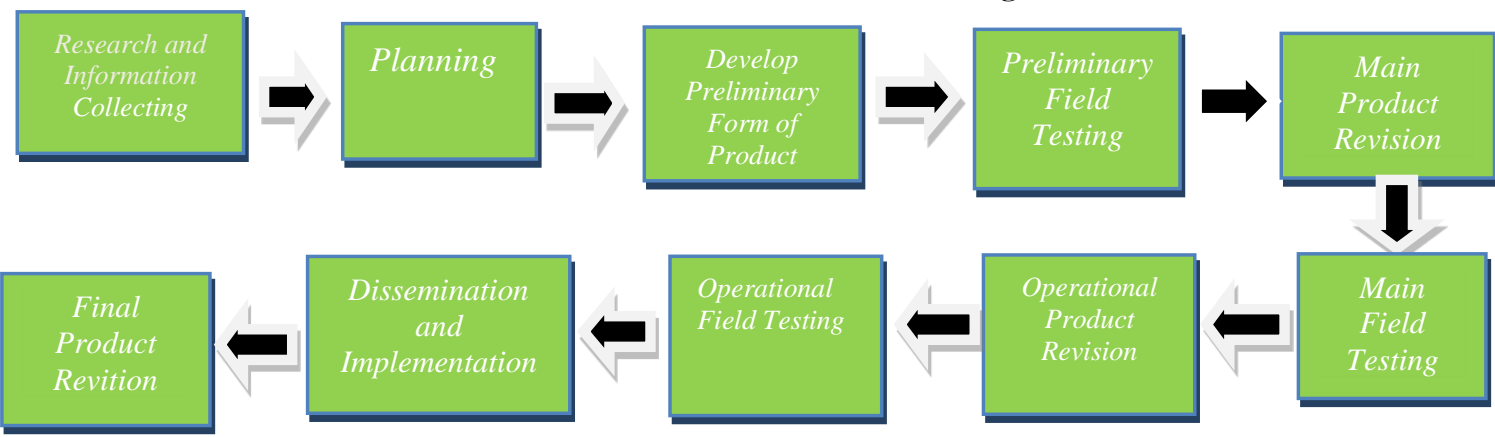


Sedangkan sumber data dalam penelitian ini meliputi sumber primer dan sumber sekunder. Adapun data yang akan diolah dalam penelitian dan pengembangan ini meliputi: Data penilian tim ahli, data penilaian respon siswa, data penilaian keterampilan proses dasar sains, data hasil belajar siswa.

\section{Instrumen Pengumpulan Data}

Instrumen pengumpulan data yang digunakan dalam penelitian ini, berupa lembar angket, lembar observasi dan butir soal. Setelah data-data tersebut diolah, maka tahap selanjutnya mengubah nilai tiap aspek dalam masing-masing komponen menjadi nilai kualitatif sesuai dengan kriteria kategori penilaian ideal. Berdasarkan penjelasan tersebut, maka penelitian ini menetapkan kreteria ideal produk (modul) minimal B (baik). Oleh karena itu, jika para ahli memberikan nilai akhir B (baik), maka produk pengembangan ini layak digunakan dalam proses pembelajaran.

\section{Interval Skor Analisis Data}

Berdasarkan hasil persentase yang diperoleh berdasarkan hasil perhitugan analisis data, maka tahap selanjutnya mengkategorikan hasil perhitungan(Ridwan dan Sunarto,2013:23) dengan ketentuan sebagai berikut:

Tabel 1: Interval Skor Analisis Data

\begin{tabular}{lll}
\hline No & Interval Skor & Kategori \\
\hline 1 & $81 \%-100 \%$ & Sangat Baik \\
2 & $61 \%-80 \%$ & Baik \\
3 & $41 \%-60 \%$ & Cukup \\
4 & $21 \%-40 \%$ & Kurang \\
5 & $0 \%-20 \%$ & Sangat Kurang \\
\hline
\end{tabular}

\section{Hipotesis Penelitian}

Ho: Tidak terdapat peningkatan keterampilan proses dasar sains setelah menggunakan modul pembelajaran IPA berbaisisinkuiri terbimbing yang dikembangkan.

Ha: Terdapat peningkatan keterampilan proses dasar sains setelah menggunakan modulpembelajaran IPA berbaisisinkuiri terbimbing yang dikembangkan..

Pengujian hipotesis dalam penelitian ini menggunakan uji- t. 


\section{HASIL DAN PEMBAHASAN}

\section{Hasil Penelitian}

\section{a. Validasi Modul Pembelajaran}

Validasi ini dilakukan untuk mengetahui kelayakan modul yang dikembangkan. Oleh karena itu, pengujian kelayakan dilakukan oleh ahli materi, ahli media, ahli bahasa dan ahli pembelajaran IPA dan inkuiri terbimbing. Adapun hasil rekapitulasi validator dapat dilihat pada table di bawah ini:

Tabel 2: Hasil Rekapitulasi Validasi Modul yang Dikembangkan

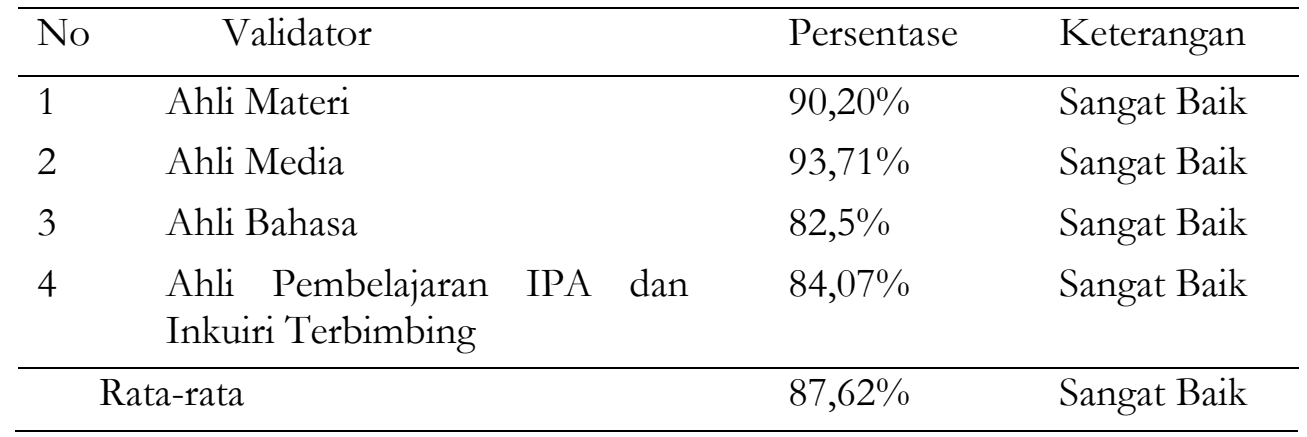

Berdasarkan tabel di atas, diketahui bahwa modul sudah memenuhi standar kelayakan dari tim ahli. Oleh karena itu, modul yang dikembangkan sudah boleh diuji coba dilapangan.

\section{b. Respon Siwa Terhadap Modul yang Dikembangkan}

Sedangkan untuk mengetahui respon siswa terhadap modul yang terapkan maka dilakukan uji coba penerapan modul yang melibatkan 25 siswa kelas IV MIN Kebonagung Yogyakarta. Adapun hasil respon siswa dapat dilihat pada tabel di bawah ini:

Tabel 3. Hasil Rekapitulasi Angket Respon Siswa

\begin{tabular}{clcc}
\hline No & \multicolumn{1}{c}{ Aspek } & Persentase & Keterangan \\
\hline 1 & $\begin{array}{l}\text { Warna, gambar, ilustrasi, bentuk dan ukuran hurup } \\
\text { pada sampul modul menarik }\end{array}$ & 91,2 & Sangat Baik \\
2 & $\begin{array}{l}\text { Bagian isi modul sudah menempatkan gambar atau } \\
\text { ilustrasi, menggunakan huruf yang dicetak tebal dan } \\
\text { miring yang menarik }\end{array}$ & S3,6 & Sangat Baik \\
\hline
\end{tabular}




\begin{tabular}{|c|c|c|c|}
\hline 3 & $\begin{array}{l}\text { Bentuk dan ukuran huruf yang digunakan tetap dari } \\
\text { halaman pertama sampai terakhir }\end{array}$ & 99,2 & Sangat Baik \\
\hline 4 & Bentuk dan ukuran huruf mudah di baca & 99,2 & Sangat Baik \\
\hline 5 & $\begin{array}{l}\text { Kegiatan dalam modul membuat saya melakukan } \\
\text { berbagai kegiatan dalam pembelajaran }\end{array}$ & 93,6 & Sangat Baik \\
\hline 6 & $\begin{array}{l}\text { Sudah terdapat kegiatan mengamati, mengukur, } \\
\text { mengklasifikasi, memprediksi, mengkomunikasi } \\
\text { dan menyimpulkan }\end{array}$ & 92 & Sangat Baik \\
\hline 7 & $\begin{array}{l}\text { Sudah terdapat pertanyaan di setiap sub bab dalam } \\
\text { modul }\end{array}$ & 93,6 & Sangat Baik \\
\hline 8 & $\begin{array}{l}\text { Sudah terdapat kegiatan investigasi atau } \\
\text { penyelidikan dalam modul }\end{array}$ & 92,8 & Sangat Baik \\
\hline 9 & Kalimat yang digunakan mudah dimengerti & 91,2 & Sangat Baik \\
\hline & Rata-rata & 94,04 & Sangat Baik \\
\hline
\end{tabular}

\section{c. Keterampilan Proses Dasar Sains}

Untuk mengetahui ada tidaknya peningkatan keterampilan proses dasar sains dengan menggunakan model pembelajaran IPA berbasis inkuiri terbimbing yang dikembangkan, maka dilakukan perbadingan keterampilan proses dasar sains sebelum dan sesudah menggunakan modul yang dikembangkan. Adapun hasil perhitungan keterampilan proses dasar sains dianalisis menggunakan SPSS 18.0, menggunakan uji paired sample t-test. Adapun hasil perhitungan hasil penilaian keterampilan proses dasar sains siswa pada sebelum $\left(\mathrm{X}_{1}\right)$ dan sesudah $\left(\mathrm{X}_{2}\right)$, dapat dilihat pada tabel di bawah ini:

Tabel 4. Hasil Perhitungan Keterampilan Proses Dasar Sains Siswa

Paired Samples Statistics

\begin{tabular}{|c|c|c|c|c|c|}
\hline & & Mean & $\mathrm{N}$ & Std. Deviation & $\begin{array}{l}\text { Std. Error } \\
\text { Mean }\end{array}$ \\
\hline \multirow[t]{2}{*}{ Pair 1} & Sebelum & 35.2400 & 25 & 3.76696 & .75339 \\
\hline & Sesudah & 39.0000 & 25 & 4.52769 & .90554 \\
\hline
\end{tabular}


Paired Samples Correlations

\begin{tabular}{|l|r|r|r|}
\hline & \multicolumn{1}{|c|}{$\mathrm{N}$} & Correlation & \multicolumn{1}{c|}{ Sig. } \\
\hline Pair 1 sebelum \& sesudah & 25 & .220 & .291 \\
\hline
\end{tabular}

Paired Samples Test

\begin{tabular}{|c|c|c|c|c|c|c|c|c|}
\hline & \multicolumn{5}{|c|}{ Paired Differences } & \multirow[b]{3}{*}{$\mathrm{T}$} & \multirow[b]{3}{*}{ Df } & \multirow[b]{3}{*}{ Sig. (2-tailed) } \\
\hline & \multirow[b]{2}{*}{ Mean } & \multirow{2}{*}{$\begin{array}{c}\text { Std. } \\
\text { Deviation }\end{array}$} & \multirow{2}{*}{$\begin{array}{l}\text { Std. } \\
\text { Error } \\
\text { Mean }\end{array}$} & \multicolumn{2}{|c|}{$\begin{array}{l}95 \% \text { Confidence } \\
\text { Interval of the } \\
\text { Difference }\end{array}$} & & & \\
\hline & & & & Lower & Upper & & & \\
\hline $\begin{aligned} \text { Pair } 1 & \begin{array}{l}\text { sebelum - } \\
\text { sesudah }\end{array}\end{aligned}$ & -3.76000 & 5.21440 & 1.04288 & -5.91240 & -1.60760 & -3.605 & 24 & .001 \\
\hline
\end{tabular}

\section{Pembahasan Hasil Penelitian}

Validasi Ahli meliputi ahli materi, ahli media, ahli bahasa dan ahli pembelajaran IPA dan inkuiri terbimbing. Validator materi dalam modul IPA berbasis inkuiri terbimbing yang dikembangkan divalidasi oleh seorang dosen Biologi Fakultas Sainstek sekaligus dosen pembelajaran Sains MI program pascasarjana Universitas Islam Negeri Sunan Kalijaga dengan persentase $\mathbf{9 0 , 2 0 \%}$ dengan kategori sangat baik sehingga layak untuk diterapkan dalam pembelajaran IPA Kelas IV MI/SD. Kelayakan tersebut diperoleh karena modul yang dikembangkan memenuhi standar pembuatan modul dengan cara melengkapi karakteristik modul yang terdiri dari self instruction, self contained, stand alone, adaptive dan userfriendly. (Daryanto, 2013:9-11). Di sisi lain modul IPA berbasis inkuiri yang dikembangkan juga menyertakan semua komponen modul pembelajaran, sebagaimana menurut Sudjana dan Rifa'i komponen modul terdiri pedoman guru, lembar kegiatan siswa, lembar kerja siswa. (Nana Sudjana dan Ahmad Rifa'I, 1989:134). Di buku lain Wijaya menambahkan komponen modul juga dilengkapi dengan kunci lembar kerja, lembar tes dan kunci lembar tes. (Cece Wijaya, 1992:102).

Validator media dalam modul pembelajaran IPA berbasis inkuiri terbimbing ini adalah seorang dosen teknologi pembelajaran dari Universitas Negeri Yogyakarta dengan persentase $\mathbf{9 3 , 7 1 \%}$ dengan kategori sangat baik. Persentase tersebut 
menunjukkan bahwa modul pembeljaran IPA berbasis inkuiri terbimbing yang dikembangkan sudah layak karena sudah valid. Persentase kelayakan tersebut diperoleh karena modul yang dikembangkan sudah memperhatikan beberapa elemen yang menjadi syarat dalam pembuatan modul, sehingga dapat menunjang pelaksanaan pembelajaran yang efektif. Adapun elemen tersebut menurut Sitepu meliputi format dengan indikator Gunakan format kolom (tunggal atau multi) yang proporsional. Penggunaan kolom tunggal atau multi harus sesuai dengan bentuk dan ukuruan kertas yang digunakan. Jika menggunakan kolom multi, hendaknya jarak dan perbandingan antar kolom secara proporsional. Gunakan format kertas (vertikal/potrait atau horisontal/landscape) yang tepat. Penggunaan format kertas secara vertikal atau horizontal harus memperhatikan tata letak dan format pengetikan.(B.P Sitepu, 2014:131). Selain itu merujuk pada referensi yang lain elemen modul seperti yang dikemukan Daryanto terdiri dari organisasi dengan indikator Tampilkan peta/bagan yang menggambarkan cakupan materi yang akan dibahas dalam modul, penyusunan isi materi pembelajaran dengan urutan dan susunan yang sistematis, susun dan tempatkan naskah, gambar dan ilustrasi mudah mengerti oleh peserta didik, penyusunan antar bab, antar unit dan antar paragrap dengan susunan dan alur yang memudahkan peserta didik memahaminya, susunan antara judul, subjudul dan uraian yang mudah diikuti oleh peserta didik. Sedangkan elemen daya tarik terdiri dari indikator bagian sampul (cover) depan, dengan mengkombinasikan warna, gambar (ilustrasi), bentuk dan ukuran huruf yang serasi.Bagian isi modul dengan menempatkan rangsangan-rangsangan berupa gambar atau ilustrasi, pencetakan huruf tebal, miring, garis bawah atau warna. Tugas dan latihan dikemas sedemikian rupa sehingga menarik, bentuk dan ukuran huruf sesuai dengan perkembangan anak dan gunakan perbandingan huruf yang proporsional antar judul, sub judul dan isi naskah. Terdapat ruang (spasi kosong) dan konsistensi penulisan. (Daryanto, 2013: 13-15)

Validator bahasa dalam modul adalah dosen Bahasa Indonesia di FITK dan Pascasarjana UIN Sunan Kalijaga Yogyakarta diperoleh persentase 82,5\% dengan kriteria sangat baik. Sebagaimana yang dikatakan Prastowo bahwa modul merupakan bahan ajar yang disusun secara sistematis dengan bahasa yang mudah dipahami oleh siswa sesuai dengan tingkat pengetahuan dan usianya agar mereka dapat belajar sendiri (mandiri) dengan bantuan atau bimbingan minimal dari guru. (Andi Prastowo, 2014:209). Oleh karena itu, aspek penulisan bahasa yang harus diperhatikan dalam penulisan modul yang terdiri dari gaya bahasa, tata bahasa dan penyusunan paragraf, (Sukiman, 2012: 140-141). Senada dengan hal tersebut, maka pengembangan modul ini 
mengembangkan indikator sebagai berikut: menggunakan sapaan akrab atau kata ganti orang, kalimat yang digunakan sederhana, tunggal, pendek, tidak beranak cucu, logis dan teratur, Tidak menggunakan istilah yang sangat asing, Setiap paragraf hanya terdiri dari satu ide atau gagasan pikiran dan menggunakan bahasa yang jelas.

Sedangkan validator Pembelajaran IPA dan Inkuiri terbimbing divalidasi seorang dosen pendidikan Biologi Fakultas Sainstek UIN Sunan Kalijaga Yogyakarta dengan persentase $\mathbf{8 4 , 0 7 \%}$ dengan kriteria sangat baik, karena penilaian aspek ini meliputi dua bagian yaitu konteks IPA dan Inkuiri Terbimbing. Konteks IPA meliputi sebagai produk meliputi IPA sebagai konsep, prinsip, fakta dan hukum, sebagaimana yang dikatakan Susanto bahwa IPA sebagai produk yaitu kumpulan hasil penelitian yang telah dilakukan para ilmuwan dan sudah membentuk konsep yang telah dikaji sebagai kegiatan empiris dan kegiatan analitis. Oleh karena itu, IPA sebagai produk meliputi fakta-fakta, prinsip dan hukum. (Ahmad Susanto, 2015:168). Konteks IPA sebagai proses meliputi berbagai kegiatan-kegiatan yang melibatkan pengembangan keterampilan siswa, sebagai mana yang dikatakan Hungerford, Volk dan Ramsey dalam Fatonah dan Prasetyo, sains sebagai proses merupakan rangkaian kegiatan ilmiah atau hasil-hasil observasi terhadap penomena alam untuk menghasilkan pengetahuan ilmiah (scientific knowledge). (Siti Fatonah dan Zuhdan K. Prasetyo, 2014:7).

Sedangkan IPA sebagaimana yang dikatakan Wyme Harlen dalam Sulistyorini setidak-tidaknya ada sembilan aspek sikap dari ilmiah yang dapat dikembangkan pada anak usia SD/MI, yaitu rasa ingin tahu, rasa ingin mendapatkan sesuatu yang baru, sikap kerjasama, sikap tidak putus asa, sikap tidak berprasangka, sikap mawas diri, sikap bertanggung jawab, sikap berpikir bebas dan sikap kedisiplinan diri.(Sri Sulistyorini, 2007:10). Akan tetapi dalam penelitian ini membatasi pada sikap ingin tahu sebagai bagian sikap ilmiah adalah suatu sikap yang selalu ingin mendapatkan jawaban yang benar dari objek yang diamati. Anak usia SD/MI mengungkapkan rasa ingin tahunya dengan jalan bertanya kepada guru, temannya dan diri sendiri. Sikap kerjasama dapat dikembangkan melalui kerja kelompok dalam rangka memperoleh pengetahuan yang lebih banyak. Sedangkan sikap tidak bekerjasama dapat dikembangkan ketika siswa melakukan diskusi, percobaan, simulasi atau kegiatan di lapangan. Sedangkan indikator Inkuiri terbimbing merujuk pada tahapan pelaksanaan inkuiri terbimbing yang terdiri dari ask, investigate, create, discuss and reflect. Sebagaimana yang ditulis Aprilia inkuiri terbimbing terdiri dari tahap-tahap Ask yaitu guru memulai proses inkuiri dengan merumsukan topik pembelajaran dalam bentuk pertanyaan dan kemudian mendorong dan mengarahkan tanggapan siswa untuk membangun iklim inkuiri. Investigate, setelah 
pertanyaan siswa disepakati selanjutnya melakukan penyelidikan. Create, guru membimbing siswa untuk membuat sintesis dan memulai berpikir kritis tentang kesesuain pertanyaan atau hipotesisnya dalam mendefinisikan kembali pertanyaan atau hal yang baru. Discuss, siswa mendiskusikan dan membahas temuannya dalam kelompok belajar di kelas, seperti membandingkan catatan, membahas kesimpulan, dan berbagi pengalaman diseluruh kelompok. Reflect, pada tahap ini siswa diharapkan dapat merefleksikan pengetahuan yang baru diperoleh.(Rosety Aprilia, 2014: 41).

\section{Respon Siswa}

Berdasarkan hasil perhitungan angket respon siswa terhadap modul yang dikembangkan seperti pada tabel 3 di atas, diperoleh rata-rata 94,04\% dengan kategori sangat baik. Rata-rata tersebut diperoleh berdasarkan aspek warna, gambar, ilustrasi, bentuk dan ukuran hurup pada sampul modul menarik 91,2\% dengan kategori sangat baik. Bagian isi modul sudah menempatkan gambar atau ilustrasi, menggunakan huruf yang dicetak tebal dan miring yang menarik $\mathbf{9 3 , 6 \%}$ dengan kategori sangat baik. Hal ini sejalan dengan pendapat Daryanto yang menyatakan bahwa daya tarik modul dapat ditempatkan di beberapa bagian yaitu Bagian sampul (cover) depan, dengan mengkombinasikan warna, gambar (ilustrasi), bentuk dan ukuran huruf yang serasi. Bagian isi modul dengan menempatkan rangsangan-rangsangan berupa gambar atau ilustrasi, pencetakan huruf tebal, miring, garis bawah atau warna.(Daryanto, 2013:13).

Bentuk dan ukuran huruf yang digunakan tetap dari halaman pertama sampai terakhir 99,2 dengan kategori sangat baik, sebagaimana yang dikatakan Sitepu untuk tingkat SD/MI kelas 3-4 menggunakan ukuran huruf 12-14 font size dengan bentuk huruf Sans Serif dan Serif. (B.P Sitepu, 2014:140). Indikator bentuk dan ukuran huruf mudah di baca 99,2\% dengan kategori sangat baik, karena penulisan modul hanya menggunakan huruf kapital yang sesuai dengan EYD, seperti yang dikemukakan Sitepu hindari penggunaan huruf kapital untuk seluruh teks, karena dapat membuat proses membaca menjadi sulit. Oleh karena itu, huruf kapital yang digunakan mengikuti ketentuan EYD biasanya digunakan pada awal kalimat, nama orang atau singkatan. (B.P Sitepu, 2014, 140). Kegiatan dalam modul membuat saya melakukan berbagai kegiatan dalam pembelajaran $\mathbf{9 3 , 6} \%$ dengan kategori sangat baik, karena modul merupakan modul juga dapat dirumuskan sebagai suatu unit yang lengkap yang berdiri sendiri dan terdiri atas suatu rangkaian kegiatan belajar yang disusun untuk membantu siswa 
mencapai sejumlah tujuan yang dirumuskan secara khusus dan jelas. (S. Nasution, 2013:205).

Modul yang dikembangkan sudah terdapat kegiatan mengamati, mengukur, mengklasifikasi, memprediksi, mengkomunikasi dan menyimpulkan $\mathbf{9 2 \%}$ dengan kategori sangat baik, karena modul yang dikembangkan bertujuan untuk meningkatkan keterampilan proses dasar sains, sebagaimana mengutif pendapat Zebra yang mengatakan The basic science process skill because they form the foundation for later and more complex thinking skill (Richard J. Rezba, dk, 1995:vii), (dikatakan keterampilan proses dasar karena keterampilan ini menjadi dasar yang harus dipahami sebelum mengarah kepada keterampilan berpikir yang lebih kompleks). Oleh karena keterampilan proses dasar sains terdiri dari yang terdiri dari keterampilan melakukan observasi, komunikasi, mengklasifikasi, mengukur, menyimpulkan, dan memprediksi. Sudah terdapat pertanyaan di setiap sub bab dalam modul 93,6\% dengan kategori sangat baik. Sudah terdapat kegiatan investigasi atau penyelidikan dalam modul $\mathbf{9 2 , 8 \%}$ dengan kategori sangat baik. Kalimat yang digunakan mudah dimengerti $\mathbf{9 1 , 2} \%$ dengan kategori sangat baik, karena kalimat dalam satu paragraph disusun secara logis dan sistematis berdasarkan ide pokok. Sebagaimana yang dikatakan Daryanto paragraf berisi kumpulan beberapa kalimat yang disusun secara logis, sehingga membentuk satu kesatuan utuh dari sebuah ide/pokok pikiran. Oleh karena itu, paragraf yang ditulis hendaknya mengarah pada suatu uraian yang menuju pada suatu pokok pikiran yang dikandung oleh kalimat utama yaitu kalimat inti pada suatu paragraf yang mengandung kunci gagasan atau ide. (Daryanto, 2013:49). Maka, setiap paragraf sebaiknya hanya terdiri dari satu ide pokok atau gagasan pikiran yang tertuang dalam kalimat utama (Sukiman, 2012:140).

\section{Keterampilan Proses Dasar Sains Siswa}

Setelah modul dinyatakan layak, maka tahap selanjutnya melakukan uji coba modul di sekolah untuk mengetahui ada tidaknya peningkatan keterampilan proses dasar sains siswa sebelum dan sesudah menggunakan modul pembelajaran IPA berbasis inkuiri terbimbing. Selama proses uji coba lapangan dengan menerapkan modul pembelajaran IPA berbasis inkuiri terbimbing yang telah dikembangkan, untuk memudahkan melakukan penialaian keterampilan proses dasar sains peneliti dibantu seorang guru IPA sekaligus guru kelas IV sebagai observer untuk melakukan pengamatan keterampilan proses dasar sains yang disesuiakan dengan lembar observasi 
yang sudah peneliti berikan. Selain itu, peneliti juga meminta observer untuk menulis temuan yang ditemukan dalam proses pembelajaran.

Oleh karena itu, ketika pengambilan data peneliti bersama observer melakukan pengamatan terhadap keterampilan proses dasar sains siswa selama menggunakan modul yang dikembangkan dalam proses pembelajaran dan menuliskan hasil pengamatannya pada lembar observasi yang telah peneliti berikan. Pada tahap ini siswa sudah mulai terbiasa menggunakan modul pembelajaran IPA berbasis inkuiri terbimbing, misalnnya pada pembelajaran 3 siswa diminta untuk melakukan praktikum tentang membuat roti, siswa sudah bisa menentukan ukuran berat $200 \mathrm{gr}$ tepung terigu menggunakan neraca pegas, membandingkan perbandingan ukuran satu sendok makan gula pasir dengan satu sendok garam dapur, mengukur perbedaan roti sebelum dan sesudah mengembang, menceritakan pengalamannya tentang membuat roti. Sedangkan pada pembelajaran 4 siswa diajak keluar kelas untuk mengamati sumber daya alam yang terdapat disekitar sekolah. Pada kegiatan ini, siswa secara berkelompok diminta untuk menuliskan sumber daya alam apa yang ada disekitar lingkungan sekolahnya dan menceritakan bagaimana cara masyarakat mengolah sumber daya alam tersebut. Pada tahap ini dengan antusias siswa menceritakan pengalamannya tentang pemanfaatan sumber daya alam yang ada disekitar lingkungan sekolah.

Adapun hasil perhitungan keterampilan proses dasar sains pada tahap pra penelitian $\left(\mathrm{X}_{1}\right)$ dan uji coba kedua $\left(\mathrm{X}_{3}\right)$ menggunakan SPSS 18.0, kemudian data tersebut di analisis menggunakan uji paired sample t-test. Adapun hasil perhitungan hasil penilaian keterampilan proses dasar sains dapat dilihat pada tabel di bawah ini:

Tabel 5. Hasil Perhitungan Keterampilan Proses Dasar Sains Siswa

Paired Samples Test

\begin{tabular}{|c|c|c|c|c|c|c|c|c|}
\hline & \multicolumn{5}{|c|}{ Paired Differences } & \multirow[b]{3}{*}{$\mathrm{T}$} & \multirow[b]{3}{*}{ Df } & \multirow[b]{3}{*}{ Sig. (2-tailed) } \\
\hline & \multirow[b]{2}{*}{ Mean } & \multirow{2}{*}{$\begin{array}{c}\text { Std. } \\
\text { Deviation }\end{array}$} & \multirow{2}{*}{$\begin{array}{l}\text { Std. Error } \\
\text { Mean }\end{array}$} & \multicolumn{2}{|c|}{$\begin{array}{l}95 \% \text { Confidence } \\
\text { Interval of the } \\
\text { Difference }\end{array}$} & & & \\
\hline & & & & Lower & Upper & & & \\
\hline Pair 1 sebelum - $\begin{array}{l}\text { sesudah } \\
\text { ses }\end{array}$ & -3.76000 & 5.21440 & 1.04288 & -5.91240 & -1.60760 & -3.605 & 24 & .001 \\
\hline
\end{tabular}


Berdasarkan hasil analisis hasil perhitungan keterampilan proses dasar sains, seperti pada tabel di atas maka diperoleh hasil $t_{\text {bitung }}$ sebesar -3,605, tanda - (negatif) dalam perhitungan tersebut bukan sebagai tanda aljabar, karena itu $t_{\text {hitung }}$ sebesar -3,605 dibaca "ada selisih derajat perbedaan sebesar 3,605". Oleh karena itu, berdasarkan hasil perhitungan tersebut, maka diperoleh $t_{\text {bitung }} 3,065$ pada sedangkan $t_{\text {tabel }} 2,064$, sehingga dapat dilihat bahwa thitung $>\mathrm{t}_{\text {tabel }}$ maka $\mathrm{H}_{\mathrm{a}}$ diterima dan $\mathrm{H}_{\mathrm{o}}$ ditolak. Oleh karena itu, dapat ditarik kesimpulan bahwa terdapat perbedaan yang signifikan antara sebelum dan sesudah menggunakan modul pembelajaran IPA berbasis inkuiri terbimbing siswa kelas IV MIN Kebonagung. Berdasarkan perhitungan tersebut, makaHipotesis alternatif (Ha) yang menyatakan ada perbedaan keterampilan proses dasar sains yang signifikan antara sebelum dan sesudah menggunakan modul pembelajaran IPA berbasis inkuiri terbimbing diterima.

Oleh kaena itu, dapat ditarik kesimpulan bahwa berdasarkan analisis data yang sudah dilakukan, diperoleh nilai rata-rata pra penelitian atau sebelum menggunakan modul pembelajaran IPA berbasis inkuiri terbimbing yaitu 35,24 dan 39,00. Hal ini menunjukkan bahwa berdasarkan uji paired sample t-test terlihat ada perbedaan keterampilan proses dasar sains yang signifikan antara nilai rata-rata sebelum dan nilai rata-rata sesudah menggunakan modul pembelajaran IPA berbasis inkuiri terbimbing siswa kelas IV MIN Kebonagung. Hasil tersebut menunjukkan bahwa penerapan modul pembelajaran IPA berbasis inkuiri terbimbing yang dikembangkan dapat meningkatkan keterampilan proses dasar sains siswa kelas IV di MIN Kebonagung. Peningkatan tersebut dibuktikan dengan siswa sudah mampu merumuskan kesimpulan berdasarkan informasi yang mereka dapatkan, sudah bisa mengukur dengan dengan menggunakan alat ukur, bisa membandingan dua benda, berani menceritakan hasil observasi di depan kelas, melakukan klasifikasi sumber daya alam yang ada disekitar lingkungan sekolah dan menjelaskan serangkain kegiatan praktikum yang sudah dilakukan.

\section{KESIMPULAN}

Berdasarkan hasil penelitian, maka dapat disimpulkan bahwa:

1. Validasi modul pembelajaran IPA berbasis inkuiri terbimbing yang dikembangkan memperoleh rata-rata $\mathbf{8 7 , 6 2 \%}$ dengan kategori sangat baik. Jika dijabarkan sebagai berikut ahli materi $\mathbf{9 0 , 2 0 \%}$ dengan kategori sangat baik; ahli media 93,71\% dengan kategori sangat baik; ahli bahasa $82,5 \%$ dengan kategori sangat baik; ahli Pembelajaran IPA dan inkuiri terbimbing $\mathbf{8 4 , 0 7 \%}$ dengan kategori sangat baik. 
2. Respon siswa terhadap modul pembelajaran IPA berbasis inkuiri terbimbing yang dikembangkan melalui pemberian angket kepada siswa diperoleh persentase keidealan secara keseluruhan sebesar 94,21\% dengan kategori sangat baik(SB).

3. Peningkatan keterampilan proses dasar sains siswa kelas IV sebelum dan sesudah menggunakan modul pembelajaran IPA berbasis inkuiri terbimbing yang dikembangkan dinilai berdasarkan hasil observasi keterampilan proses dasar, kemudian dianalisis menggunakan perhitungan statistik SPSS 18.0 dengan uji paired sample t-test. Berdasarkan hasil perhitungan keterampilan proses dasar sains pada Berdasarkan uji coba tersebut diperoleh $t_{\text {bitung }}$ 3,065 sedangkan $t_{\text {tabel }}$ 2,064, sehingga dapat dilihat bahwa thitung $>t_{\text {tabel }}$ maka $H_{a}$ diterima dan $H_{o}$ ditolak. Sehingga berdasarkan perhitungan tersebut, terdapat keterampilan proses dasar sains yang signifikan setelah menggunakan modul pembelajaran IPA berbasis inkuiri terbimbing atau dengan kata lain modul pembelajaran IPA berbasis inkuiri terbimbing yang dikembangkan dapat meningkatkan keterampilan proses dasar sains siswa kelas IV MI/SD. Sehingga modul ini valid dan layak digunakan dalam proses pembelajaran IPA khususnya pada materi hubungan sumber daya alam dengan lingkungan, teknologi dan masyarakat dalam rangka meningkatkan keterampilan proses dasar sains siswa kelas IV MI/SD.

\section{DAFTAR PUSTAKA}

Andi Prastowo. 2014. Pengembangan Bahan Ajar Tematik: Tinjauan Teoritis dan Praktis. Cet. ke-1. Jakarta: Kencana Prenada Media Group.

Daryanto. Menyusun Modul: Bahan Ajar Untuk Persiapan Guru Dalam Mengajar. Yogyakarta: Gava Media. 2013.

Hayati, Ai dan Poppy Anggraeni. Analisis Profil Keterampilan Proses Sains Siswa Sekolah Dasar di Kabupaten Sumedang. Jurnal Pesona Dasar. Vol. 5 No. 2 Oktober 2017.

J. Rezba, Richard dkk. Learning and Assesing Science Process Skill, Thrid Edition. United State America: Kendal/Hunt Publishing Company.1995.

Juhji. Peningkatan Keterampilan Proses Sains Siswa melalui Pendekatan Inkuiri Terbimbing. Jurnal Penelitian dan Pembelajaran IPA. Volume 2 No. 1 Juni 2016.

Nasution, S. Berbagai Pendekatan dalam Proses Belajar dan Mengajar. Jakarta: Bumi Aksara. 2013. 
Nurhidayah, Rizki, dkk., "Pengembangan Modul Berbasis Inkuiri Terbimbing pada Materi Larutan Elektrolit dan Non-elektrolit', EDUSAINS: Jurnal UIN Jakarta, Pendidikan Kimia Fakultas Ilmu Tarbiyah dan Keguruan UIN Syarif Hidayatullah Jakarta, Volume 7 No 1 Tahun 2015.

Riduwan dan Sunarto. Pengantar Statistika untuk Penelitian Pendidikan, Sosial, Ekonomi, Komunikasi, dan Bisnis. Bandung: Alfabeta. 2013

Rosety Apriliya, Implementasi Metode Inkuiri untuk Meningkatkan Keterampilan Proses Sains dan Sikap Ilmiah Siswa Pada Pembelajaran IPA Kelas V di MIN Pajangan Bantul Yogyakarta. Tesis. Yogyakarta: UIN Sunan Kalijaga. 2014.

Semiawan, Conny dkk. Pendekatan Keterampilan Proses Bagaimana Mengaktifkan Siswa dalam Belajar. Jakarta: Gramedia. 1990.

Sitepu, B.P. Penulisan Buku Teks Pelajaran. Cet ke-2. Bandung: Remaja Rosdakarya. 2014.

Siti Fatonah dan Zuhdan K. Prasetyo. 2014. Pembelajaran Sains. Yogyakarta: Ombak.

Sugiono. Metode Penelitian dan Pengembangan: Research and Development. Bandung: Alfabeta. 2015

Sukiman. Pengembangan Media Pembelajaran. Yogyakarta: Pedagogia, 2012.

Sudjana, Nana dan Ahmad Rivai. Teknologi Pengajaran. Bandung: Sinar Baru. 1989

Susanto, Ahmad. Teori Belajar dan Pembelajaran di Sekolah Dasar. Cet ke-3. Jakarta: Kencana Prenada Media Group. 2015.

Sulityorini, Sri. Model Pembelajaran IPA Sekolah Dasar dan Penerapannya dalam KTSP. Yogyakarta: Tiara Wacana. 2007.

Trianto. 2009. Mendesain Model Pembelajaran Inovatif-Progresif. Jakarta: Kencana Prenada Media Group.

Wijaya, Cece.,dkk. Upaya Pembaharuan dalam Pendidikandan Pengajaran. Bandung: Remaja Rosdakarya. 1992.

Widayanti, Esti Yuli. Penguasaan Keterampilan Proses Sains Dasar Siswa Madrasah Ibtidaiyah (Studi Pada Madrasah Mitra STAIN Ponorogo). Jurnal Kodifikasia. Vol 9 No. 1 Tahun 2015.

Zainal Arifin. Penelitian Pendidikan Metode dan Paradigma Baru. Bandung: Remaja Rosdakarya. 2011 